\title{
Relation Between Intelligence And Other Cognitive Abilities Of Monolinguals And Bilinguals
}

\author{
Preeti Gulati $^{1}$ Dr. Davinder Singh Johal ${ }^{2}$ \\ ${ }^{1}$ Department Of Psychology, S.R. Goverment College, Amritsar, Punjab,India \\ ${ }^{2}$ Department Of Psychology, Guru Nanak Dev University, Amritsar,Punjab,India
}

\begin{abstract}
The present study was conducted to assess the relation of cognitive abilities of monolinguals and bilinguals to intelligence. The sample of 200 monolinguals (100 and 100 girls) and 200 bilinguals (100 and 100 girls) was selected from different schools of Amritsar city. Different measures of intelligence, problem solving ability, concept formation and creativity were administered on the subjects. The data collected was further subjected to correlational analysis; the results indicated that both bilinguals and monolinguals showed high and positive correlation of intelligence with measure of creativity (i.e. Fluency, Flexibility, Originality and Elaboration) except verbal flexibility in case of bilinguals and figural originality in terms of monolinguals. Whereby bilinguals showed a positive relation between intelligence and problem solving abilities and monolinguals do not. Both the linguistic groups showed the similar relation between intelligence and conceptual development.
\end{abstract}

KEYWORDS: Bilinguals, Cognitive Abilities, Correlation, Intelligence, Monolinguals. ${ }^{I}$ Assistant Professor, Department of Psychology, S.R. Government College, Amritsar, Punjab, India.

${ }^{2}$ Associate Professor, Department Of Psychology, Guru Nanak Dev University, Amritsar, Punjab, India.

\section{INTRODUCTION}

Language broadens the human mind, open up new areas of cognitive abilities and help in organizing the external as well as inner realities not only of the individual but also of the world. Human beings have been using language for thousands of years and communicating their ideas, thoughts and views with each other. This is also the fact that thinking is not possible without language. As no relation is one sided, thought too has an intimate relation to language. Language can be defined as system of rules and symbols used for communication. Linguistic relativity theory suggested that language is shaped and determined by thought. People who speak different languages perceive the world differently because thinking is determined by words being used frequently in the communication [1]. Many philosophers, and more recently psychologists and linguistics have given place of privilege to cognition, in an effort to explain language as a faculty determined by the nature of the human mind. Right from the beginning it has been realized that language plays a dominant role in lending a concrete shape to human thinking. The factors that contribute to develop this realization include a linguistic analysis of radically different languages, the 'linguistic turn' in philosophy in the mid-20 $0^{\text {th }}$ century and the application of socio-cultural approach in psychology [2], [3], [4]. After a period of dissensions and disputes, work of Whorf once again gained influence, and various interpretations of 'his thesis of linguistic relativity' were being discussed and debated [1]. Piaget believed that language and thought are autonomous [5]. Acquisition of more than one language has a positive and accelerating impact on various cognitive abilities. In other simple words, whether monolinguals, bilinguals or multilinguals have any specific advantage on their performance or other related spheres such as creativity, concept formation, problem solving abilities, etc.

\subsection{MONOLINGUALISM}

Monolingual is the person who is able to speak only one language (Macquarie Dictionary) or a person/community with only one language, are called unilingual [6]. A monolingual is a person who has an active knowledge of only one language, and he has a passive knowledge of other [7].

\subsection{BILINGUALISM}

Bilingualism can be defined as "knowing two languages" [8]. However, a major difficulty centers on the definition of what it means to "know" a language. Some bilinguals are highly proficient in both languages they speak, while others clearly have a dominant or preferred language. 
Lingualism is related to various cognitive abilities like intelligence, creativity, linguistic skills, educational attainment, emotional adjustment, or overall cognitive functioning. "Bilingualism is as intelligence as food is to human fitness" [9]. It has become a matter of discussion for last thirty years, about the bilingual child and his mental abilities relating to intelligence and education. A research conducted in Montreal on ten year old children and made a comparison on monolingual and bilingual French or English concluded that bilingual subjects showed superior performance on different measures of verbal and non-verbal intelligence tests [10]. Researchers debated over a positive relationship between bilingualism and intelligence after examining the data obtained in earlier studies [11]. They pointed out that the more diversified socio-linguistic background of bilinguals favours the development of a more complex structure of mental abilities for bilinguals than for monolinguals. Bilinguals were additionally found superior on both verbal and nonverbal tests of intelligence when socioeconomic status was controlled.

A comparative study on bilingual and monolingual Iranian EFL (English as a foreign language) Learners' Linguistic Intelligence across genders aimed at comparing linguistic intelligence of Iranian bilinguals and monolinguals regarding their gender and authors found that the male participants showed no difference regarding their linguistic intelligence [12]. A study on high school students in Iran regarding bilingual and monolingual differences on selfestimates of multiple intelligences with reference to gender. Findings showed that bilingual students rated themselves higher on linguistic, logical mathematical, spatial, and interpersonal intelligences than monolingual peers while monolingual students rated themselves higher on intrapersonal intelligence than bilingual students. Moreover, the male students gave higher self-estimates for logical-mathematical, spatial, and bodily kinesthetic intelligences than their female peers while female students gave higher self-estimates for linguistic, interpersonal and intrapersonal intelligences than their male peers [13].

In examining the relationship between bilingualism, intelligent quotient and errors made by learners in their attempt to master the rules of the target languages the author showed the complex relationship between intelligent quotient and linguistic performance. The mistakes which occur at phonological, syntactic, semantic and stylistic levels in a written discourse of foreign language learning by the student are part and parcel of the learning process and may not be considered as the sign of lack of intelligence on the part of the learner. Thus, the authors concluded that there is a correlation between intelligent quotient and bilingualism and errors or mistakes committed have to be tactfully handled by the teachers by giving a positive feedback to the students and making them more apt in learning a foreign language [14].

Lingualism is also related to problem solving ability, concept formation and creativity. Many researchers think that problem solving is enhanced by learning two languages and thus increases the individual's capability to deal effectively with problems. Various researchers support the positive relationship between bilingualism and mathematics [15], [16], [17]. On comparing the bilingual Papua New Guinea students with monolinguals on two types of mathematics problems i.e. general mathematics and mathematical word problem test, it was found that students who were competent in both their languages outperformed monolingual counterparts [18].

Various studies have suggested that the effect of language factors on problem solving in mathematics probably depends on the level of mathematical abstractness of the specific component processes involved. Various theorists of word problem solving have proposed that solving a word problem involved a complex and interrelated set of informationprocessing components [19], [20]. These components may vary in their level of mathematical abstractness or the degree to which the processes involve the manipulation or transformation of mathematical concepts into mathematical symbolic representations. Bialystok found that bilingual children outperformed their monolingual peers in a dimensional change card sorting task, which required the participants to shift the criterion of classification from colour to shape [21].

After comparing the performances of several groups of monolinguals and bilinguals from different ages on the Simon Task, a task that requires participants to inhibit a prepotent response tendency, authors found that bilinguals again outperformed monolinguals [22]. A comparative study of language learning strategies used by monolingual and bilingual EFL (English as First Language) learners presented an empirical evidence of language learning differences between monolinguals and bilinguals in terms of the learning strategy they used. Monolingual and bilingual university students employed a wide variety of language learning strategies (memory, cognitive, compensational, meta- cognitive, affective and social) to learn English more effectively and bilingual learners on average have employed these strategies more than their monolingual peers [23].

On investigating the cognitive benefits of bilingualism in children, who speak the minority languages of Sardinian and Scottish Gaelic, in addition to their respective 'national' languages of Italia and English the bilingual children were seen significantly better than monolingual children in two of the four sub-tests i.e. (Block Design and Vocabulary) and the Scottish children significantly performed better than the Sardinian children in one of the sub-tests i.e. (Arithmetic). The differences found were largely due to the superior performance of the Scottish bilingual children who receive a formal bilingual education, in contrast to the Sardinian bilingual children who mostly speak the minority language at home [24].Various researches coined that bilinguals demonstrate advantages over monolinguals on concept 
formation. Researchers proposed that bilingual children show cognitive advantages as they are better able to dissociate concepts from the words with, which they are verbalized [10]. Some demonstrated through their study that bilingual children are at advantage in conceptualizing object constancy and naming and labelling tasks in comparison to monolinguals [25]. Lidtke \& Nelson too showed differences between bilinguals and monolinguals on a concept formation task [26]. Ianco-Worrall examined four and five year old bilingual children and studied the relationship between object-naming ability and bilingualism. Fifty-Four percent of these children consistently chose to interpret words in semantic dimensions and only two children among the monolingual group showed similar choice behaviour. A higher percentage of the bilinguals perceived a relationship between words in their symbolic meaning rather than their sounds [27]. Bilingual and monolingual preschooler's performance on a card sort task where children were asked to first sort a set of cards (blue and red circle and squares) according to their colors and then sort the cards according to their shape, the results clearly indicated that bilinguals were superior in performance in comparison to monolingual children [21]. Recently others observed small differences in dual task processing and in the magnitude of the Simon effect between bilingual and monolingual university undergraduate students [28], [29].

Researchers indicated strong relationship between creativity and lingualism and this relationship has been shown by numbers of investigators in their referred studies. The relationship between bilingualism and creativity of 9 to 11 years old Nigerian and Welsh children was studied and found that bilingual children scored significantly higher on verbal creativity tests than their monolingual counterparts. However, no significant differences were found between the groups with respect to figural creativity [30]. Wang also initiated similar results favouring bilingual student on same creativity measures. She found that Chinese-English speaking balanced bilinguals scored significantly higher than English speaking monolinguals of Chinese background on verbal associational fluency, ideational fluency and verbal and figural flexibility whereas no differences between the groups were found in relation to verbal expressional fluency and figural flexibility [31].

Bilingual participants outperformed their monolingual counterparts on fluency, flexibility, and elaboration in divergent thinking tasks and were superior in the divergent thinking traits which resulted from the processes that activated and elaborated on a large number of concepts from diverse categories, earlier defined as generative capacity [32]. Kharkhurin further revealed that the Farsi-English bilingual participants significantly outperformed their Farsi monolingual counterparts, on the invariants i.e. the bilinguals exhibited greater innovative capacity and showed no significant differences with their monolingual counterparts in the generative capacity [33]. He also analysed whether bilingualism has a measurable contribution to verbal and non verbal creative performance and compared the performance of Russian-English bilingual and English monolingual college students (residing in the USA) on the verbal and non verbal indicators of the abbreviated Torrance test for adults. The results obtained established that the monolingual group acquired significantly higher scores compared with the bilingual group in verbal indicators of richness and colorfulness of imagery and future orientation. On the other side, bilingual group scored significantly higher than monolingual counterparts on the non verbal indicators of richness and colorfulness of imagery and resistance of premature closure [34].

On exploring relationship among different degrees of bilingualism and creativity (adaptive creative style, innovative creative style, and creative strengths) it was revealed that the degree of bilingualism was positively associated with creativity, and more specifically, with the adaptive creative style and creative strengths [35]. After examining the relationship between language learning strategies and EFL learners' creativity authors concluded that there is significant relationship between EFL learners total use of language learning strategies and their creative abilities [36].A study conducted to discover the impact of bilingualism on the development of creativity in general and mathematical creativity in particular indicated that the bilingual children depicted higher creative abilities than the monolingual children [37]. A research study conducted on college learners indicated that students who had successfully completed a college level second language courses showed high and positive relation with domains of creativity (fluency, flexibility, originality, elaboration), whereas students who had not taken second language courses tend to show opposite relation to creativity measures [38]. In a study to access the possible effect of bilingualism on creativity in non-mathematical and mathematical problem solving among very young bilingual and monolingual pre-schoolers and concluded that both early bilingualism and some form of bilingual or formal education seem to influence the child's general and mathematical creativity [39].

\section{METHODOLOGY}

A sample of 200 monolingual subjects (100 boys and 100 girls) and 200 bilingual subjects (100 boys and 100 girls) were selected from different public schools of district Amritsar. While selecting the sample, socio-economic status, age of the subjects and the degree of monolingualism and bilingualism were taken into consideration. Language proficiency was assessed by reading, writing, speaking and understanding skills of the language. The students, who read, write, speak and understand only one language at all the places viz., school, home, family and friends were considered as monolinguals. On the other hand, those who can read, write, speak and understand more than one 
language at school, home and in company of friends were considered as bilinguals. The age range of the subjects along with Means and Standard Deviations has been given in the TABLE NO.1. All the subjects belonged to $8^{\text {th }}$ grade having completed 7 years of formal education. In the present study some important variables such as socio-economic status, sex, degree of lingualism, age and the actual test used (which play a crucial role in data analysis) which may have significant effects on the results were sufficiently controlled. All the subjects were divided into groups on the basis of degree of lingualism. Since subjects had varying abilities to read, write and speak different languages, so two groups of monolinguals and bilinguals were constituted to compare cognitive abilities.

Table No. 1. Frequency Distribution of Age Range of Total Number of Subjects $\quad(\mathbf{N}=\mathbf{4 0 0})$
\begin{tabular}{|c|c|}
\hline Class-Interval & $\begin{array}{c}\text { TOTAL SUBJECTS } \\
\text { Frequency }\end{array}$ \\
\hline 12years to 13 years & 49 \\
\hline 13 years to 14 years & 196 \\
\hline 14 years & 155 \\
\hline Mean & $\mathbf{1 3 . 2 6}$ \\
\hline Standard Deviation & $\mathbf{0 . 6 6}$ \\
\hline
\end{tabular}

\subsection{MEASURES USED}

A brief description of measuring instruments is given below:

(i) Language Proficiency Test[40]

The test is based on background questionnaire to assess the subject's proficiency in any particular language say for example English, Punjabi or Hindi. Test can be used to know whether the subject can speak, write and read very well in the language he/she knows. The scale is used to identify and make a distinction between monolinguals and bilinguals.

(ii) Standard Progressive Matrices[41]

The Standard Progressive Matrices (SPM: Set A, B, C, D and E) test consists of 60 problems divided into 5 sets and each set further consists of 12 items. SPM was designed to cover the widest possible range of mental ability, intellectual development of different age groups, level of education and differences of nationality and physical condition.

(iii) Problem Solving Ability Test[42]

The test consists of 20 problems related to different streams of mathematics, reasoning, etc and each problem has 4 options out of which only one is correct. The subject has to select the right option. The time limit for the test is 40 minutes. The age range was 12-17 years. One mark was assigned for correct answer and zero for wrong answer. Marks were added to get the total and find the actual score, which was taken as the problem solving ability of a student.

(iv) Concept Formation Test[43]

Hoffmann and Kansanian adopted Vygotsky’s test of conceptual thinking. Test consisted of 22 blocks which differ in colour, shape, size and height. Under each block is a nonsense syllable (MUR, BIK, LAG, and CEV). All the blocks which belong to the same conceptual category have the same syllable. One block of each category or group was shown to the subject and the subject was asked to select the blocks of the same category from the remaining blocks. Errors committed by the subject were explained to the subject and the record of errors and time taken by the subject was also recorded. Every wrong response was marked $(\mathrm{x})$, and correct response ticked $(\sqrt{ })$. The first attempt was complete when the subject selected the blocks of all the four categories. The same process was repeated till the subject succeeds in selecting the blocks without committing any error.

(v) Torrance Test of Creative Thinking[44]

The test is also known as creativity test of thinking. The test was first developed by Dr. Torrance E. Paul and his associates and was renormed five times in [45], [46], [47], [48], [49], [50]. The test has two forms namely verbal and figural. The verbal form requires written responses and figural form requires drawing or figure completion responses. In the present study both verbal and figural tests were employed. Although there have been several revisions in the verbal and figural manual of the Torrance Test of Creative Thinking (TTCT), the basic format of the test has remained unchanged. The test measured four divergent dimensions of creative thinking i.e. fluency, flexibility, originality and elaboration [51], [45]. 


\subsection{CORRELATIONAL ANALYSIS}

\section{RESULTS}

3.2. The correlational analysis measures the degree of relationship between the variables. The measure of correlation called the correlation coefficient or correlation index summarizes in one figure the direction and degree of correlation. The correlation analysis refers to the techniques used in measuring the closeness of the relationship between variables [52]. There were total 13 components and 13x13 correlational matrix was formed. A brief description of correlational analysis is given below:

Table No.2:- Intercorrelation matrix for Bilingual (Boys: N=200, Girls: N=200)

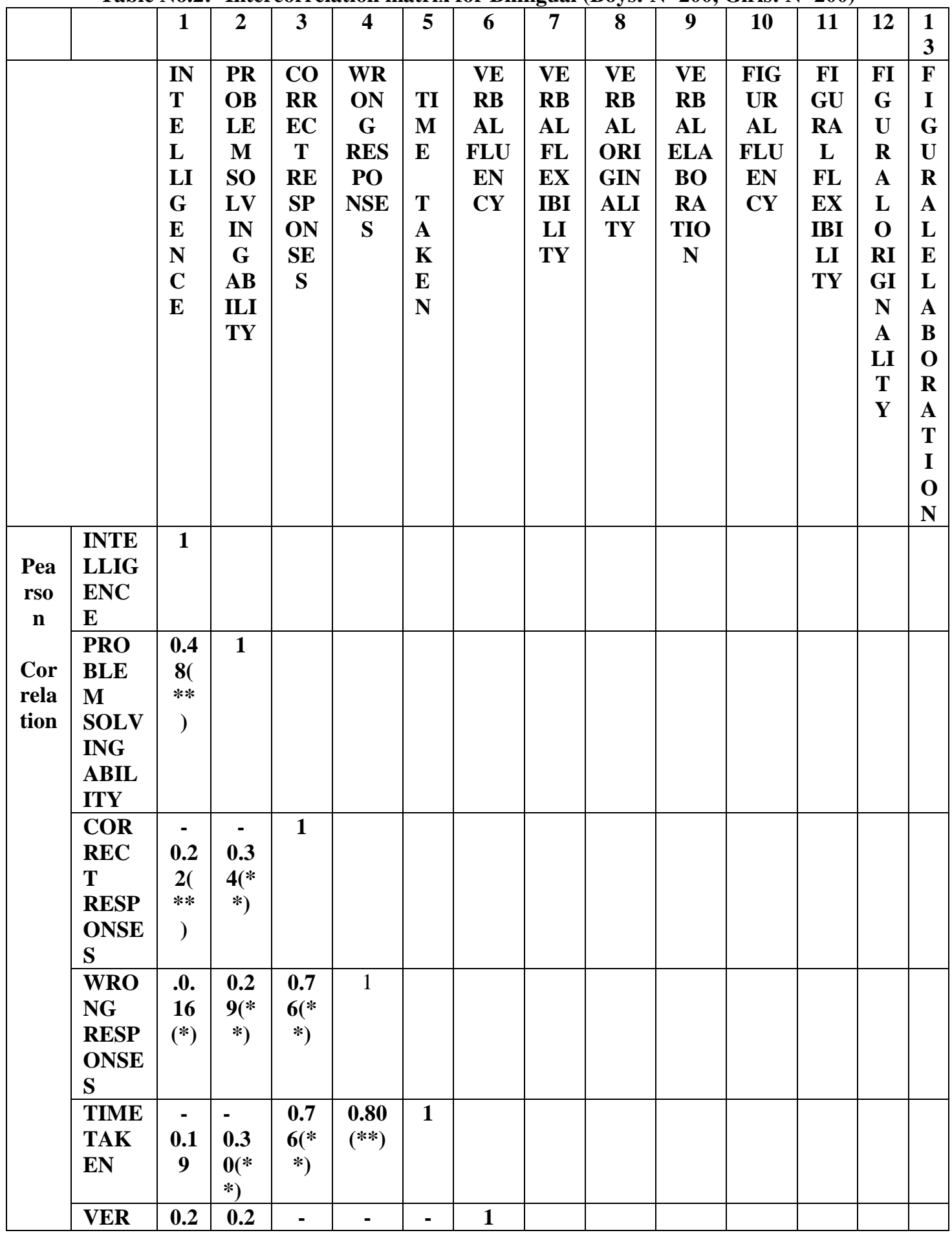




\begin{tabular}{|c|c|c|c|c|c|c|c|c|c|c|c|c|c|}
\hline $\begin{array}{l}\text { BAL } \\
\text { FLUE } \\
\text { NCY }\end{array}$ & $\begin{array}{c}8( \\
* * \\
)\end{array}$ & $\begin{array}{c}7(* \\
*)\end{array}$ & $\begin{array}{c}\mathbf{0 . 1} \\
7(* \\
)\end{array}$ & $\begin{array}{c}0.17 \\
(*)\end{array}$ & $\begin{array}{c}\text { 0. } \\
09\end{array}$ & & & & & & & & \\
\hline $\begin{array}{l}\text { VER } \\
\text { BAL } \\
\text { FLEX } \\
\text { IBILI } \\
\text { TY } \\
\end{array}$ & $\begin{array}{c}\mathbf{0 . 1} \\
3\end{array}$ & $\begin{array}{c}0.1 \\
8(* \\
*)\end{array}$ & -0.1 & -0.1 & $\begin{array}{c}- \\
0 . \\
05\end{array}$ & $\begin{array}{l}0.75 \\
(* *)\end{array}$ & 1 & & & & & & \\
\hline $\begin{array}{l}\text { VER } \\
\text { BAL } \\
\text { ORIG } \\
\text { INAL } \\
\text { ITY }\end{array}$ & $\begin{array}{l}0.1 \\
7( \\
*)\end{array}$ & $\begin{array}{c}0.2 \\
4(* \\
*)\end{array}$ & $\begin{array}{c}- \\
0.0 \\
5\end{array}$ & $\overline{0 .}$ & $\begin{array}{l}- \\
0 . \\
01\end{array}$ & $\begin{array}{l}0.74 \\
(* *)\end{array}$ & $\begin{array}{c}0.7 \\
1(* \\
*)\end{array}$ & 1 & & & & & \\
\hline $\begin{array}{l}\text { VER } \\
\text { BAL } \\
\text { ELAB } \\
\text { ORA } \\
\text { TION }\end{array}$ & $\begin{array}{c}0.2 \\
4( \\
* * \\
)\end{array}$ & $\begin{array}{c}\mathbf{0 . 0} \\
\mathbf{9}\end{array}$ & $\begin{array}{c}- \\
0.0 \\
5\end{array}$ & $\begin{array}{c}- \\
0.05\end{array}$ & $\begin{array}{c}- \\
0 . \\
02\end{array}$ & $\begin{array}{l}0.67 \\
(* *)\end{array}$ & $\begin{array}{c}0.6 \\
1(* \\
*)\end{array}$ & $\begin{array}{l}\mathbf{0 . 6 8} \\
(* *)\end{array}$ & 1 & & & & \\
\hline $\begin{array}{l}\text { FIGU } \\
\text { RAL } \\
\text { FLUE } \\
\text { NCY } \\
\end{array}$ & $\begin{array}{c}\mathbf{0 . 3} \\
\mathbf{2 (} \\
* * \\
) \\
\end{array}$ & $\begin{array}{c}0.2 \\
7(* \\
*)\end{array}$ & $\begin{array}{c}- \\
0.0 \\
7\end{array}$ & $\begin{array}{c} \\
0.09\end{array}$ & $\begin{array}{c}- \\
0 . \\
07\end{array}$ & $\begin{array}{l}\mathbf{0 . 4 0} \\
(* *)\end{array}$ & $\begin{array}{c}0.2 \\
9(* \\
*)\end{array}$ & $\begin{array}{l}\mathbf{0 . 3 1} \\
(* *)\end{array}$ & $\begin{array}{l}0.25 \\
(* *)\end{array}$ & 1 & & & \\
\hline $\begin{array}{l}\text { FIGU } \\
\text { RAL } \\
\text { FLEX } \\
\text { IBILI } \\
\text { TY }\end{array}$ & $\begin{array}{c}0.3 \\
5( \\
* * \\
)\end{array}$ & $\begin{array}{c}0.2 \\
8(* \\
*)\end{array}$ & $\begin{array}{c}- \\
0.1 \\
2\end{array}$ & $\begin{array}{c}- \\
0.13\end{array}$ & $\begin{array}{c}- \\
0 . \\
11\end{array}$ & $\begin{array}{l}\mathbf{0 . 4 0} \\
(* *)\end{array}$ & $\begin{array}{c}0.2 \\
6(* \\
*)\end{array}$ & $\begin{array}{l}\mathbf{0 . 2 4} \\
(* *)\end{array}$ & $\begin{array}{l}\mathbf{0 . 2 3} \\
(* *)\end{array}$ & $\begin{array}{l}\mathbf{0 . 8 6} \\
(* *)\end{array}$ & 1 & & \\
\hline $\begin{array}{l}\text { FIGU } \\
\text { RAL } \\
\text { ORIG } \\
\text { INAL } \\
\text { ITY } \\
\end{array}$ & $\begin{array}{c}0.3 \\
5( \\
* * \\
)\end{array}$ & $\begin{array}{c}0.2 \\
5(* \\
*)\end{array}$ & $\begin{array}{c}\mathbf{0 . 0} \\
\mathbf{0}\end{array}$ & $\begin{array}{c}- \\
0.05\end{array}$ & $\begin{array}{c}- \\
0 . \\
01\end{array}$ & $\begin{array}{c}- \\
0.37 \\
(* *)\end{array}$ & $\begin{array}{c}0.2 \\
8(* \\
*)\end{array}$ & $\begin{array}{l}\mathbf{0 . 3 0} \\
(* *)\end{array}$ & $\begin{array}{l}\mathbf{0 . 2 5} \\
(* *)\end{array}$ & $\begin{array}{l}\mathbf{0 . 7 5} \\
(* *)\end{array}$ & $\begin{array}{c}0.7 \\
7(* \\
*)\end{array}$ & 1 & \\
\hline $\begin{array}{l}\text { FIGU } \\
\text { RAL } \\
\text { ELAB } \\
\text { ORA } \\
\text { TION }\end{array}$ & $\begin{array}{l}0.4 \\
8( \\
* * \\
)\end{array}$ & $\begin{array}{l}0.2 \\
6(* \\
*)\end{array}$ & $\begin{array}{c} \\
0.1 \\
5(* \\
)\end{array}$ & $\begin{array}{c}- \\
0.17 \\
(*)\end{array}$ & $\begin{array}{c}- \\
0 . \\
12\end{array}$ & $\begin{array}{l}0.44 \\
(* *)\end{array}$ & $\begin{array}{l}\mathbf{0 . 3} \\
\mathbf{3}(* \\
*)\end{array}$ & $\begin{array}{l}\mathbf{0 . 4 1} \\
(* *)\end{array}$ & $\begin{array}{l}0.44 \\
(* *)\end{array}$ & $\begin{array}{l}\mathbf{0 . 5 9} \\
(* *)\end{array}$ & $\begin{array}{c}0.6 \\
1(* \\
*)\end{array}$ & $\begin{array}{l}\mathbf{0 .} \\
66 \\
(* \\
*)\end{array}$ & 1 \\
\hline
\end{tabular}

** Correlation is highly significant at the 0.01 level (2-tailed).

* Correlation is significant at the 0.05 level (2-tailed).

\subsection{BILINGUAL (BOYS ANG GIRLS)}

The correlational matrix of bilingual boys and girls given in Table no.2 presents the correlation between intelligence and different cognitive abilities of bilingual (boys and girls). The scores in the table indicate that the intelligence has the significant positive correlation with problem solving ability $(r=0.48)$ significant at 0.01 level. The intelligence has significantly negative relation $(\mathrm{r}=-0.16, \mathrm{r}=-0.19)$ with wrong responses and time taken respectively at 0.05 and 0.01 level. The components of verbal creativity i.e. Fluency, Originality, Elaboration are positively correlated with intelligence except Flexibility ( $r=0.28, r=0.17, r=-0.24)$ respectively. On the other hand all the components of figural Creativity (Fluency, Originality, Elaboration, and Flexibility) also show a high and significant relation with intelligence $(\mathrm{r}=0.32, \mathrm{r}=0.35, \mathrm{r}=0.35, \mathrm{r}=0.48)$. 
TABLE No.3:- Intercorrelation matrix for Monolinguals (Boys: $N=200$, Girls: $N=200$ )

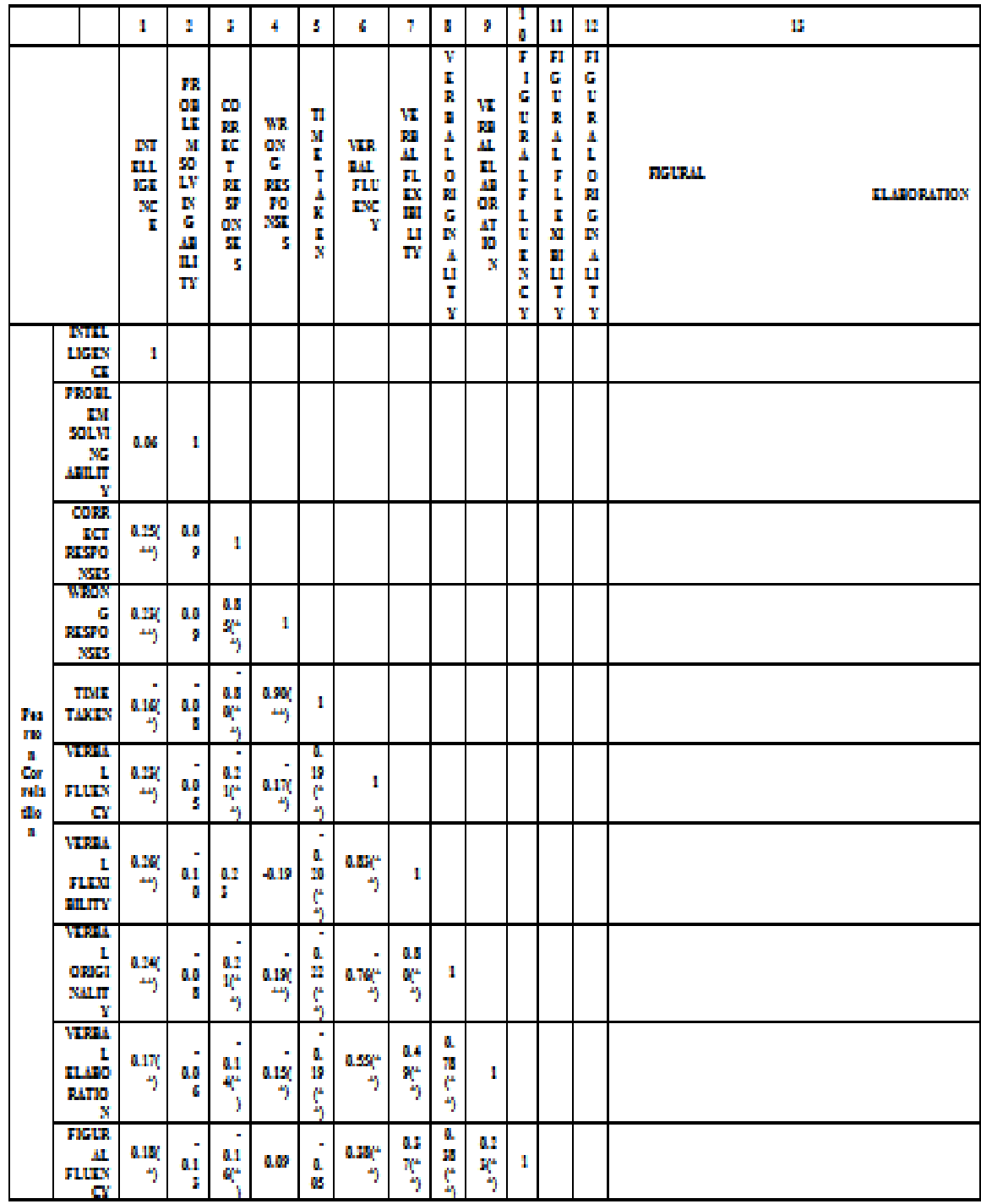

\begin{tabular}{|c|c|c|c|c|c|c|c|c|c|c|c|c|}
\hline $\begin{array}{l}\text { netr } \\
\text { nusu } \\
\text { num } \\
\text { num }\end{array}$ & $\underset{0.18}{2}$ & 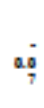 & $\frac{a, 2}{\alpha^{2}}$ & -200 & as & a.sic & 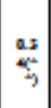 & $\begin{array}{c}\frac{a}{3} \\
c \\
5 \\
5\end{array}$ & $\begin{array}{ll}0.1 \\
0\end{array}$ & $\begin{array}{l}\vdots \\
\vdots \\
\vdots \\
\vdots \\
\vdots\end{array}$ & & \\
\hline 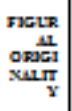 & a.t & 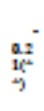 & ${ }^{2.1}$ & -200 & $a$ & a.sas & $\mid \begin{array}{c}0.3 \\
x_{3}^{2}\end{array}$ & 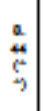 & 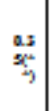 & 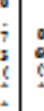 & 1 & \\
\hline 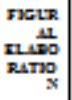 & 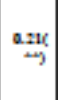 & $\frac{21}{4}$ & ${ }^{22}$ & $\begin{array}{lll}2 \times 4 \\
-3\end{array}$ & $\stackrel{2}{a}$ & asese & $\left|\begin{array}{c}a .3 \\
a_{5}^{5}\end{array}\right|$ & $\begin{array}{ll}0 \\
\vdots \\
\vdots \\
\vdots\end{array}$ & $\frac{a .4}{\alpha_{i}^{4}}$ & 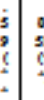 & 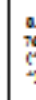 & \\
\hline
\end{tabular}

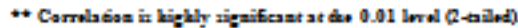

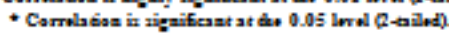




\subsection{MONOLINGUAL BOYS AND GIRLS}

The correlational matrix of Monolingual (boys and girls) is reported in Table no.3. The values indicate that in case of monolinguals intelligence is not related to problem solving abilities. On the other hand monolingual boys and girls show significant negative correlation with wrong responses and time taken $(r=-0.25, r=-0.23)$ respectively. Monolingual boys and girls show significant positive correlation with all the components of verbal creativity ( $\mathrm{r}=0.23$, $\mathrm{r}=0.26, \mathrm{r}=0.24, \mathrm{r}=0.14$ ) respectively. The Components of figural Creativity except figural originality were positively correlated with intelligence $(\mathrm{r}=0.18, \mathrm{r}=0.15, \mathrm{r}=0.21)$ at 0.01 and 0.05 level respectively.

\subsection{BILINGUAL (BOYS AND GIRLS)}

\section{DISCUSSION}

The results of correlation matrix of bilingual boys and girls shows that bilingual boys and girls have higher ability to reason are more flexible and fluent in solving the word mathematical problems and even they have ability to process the task related problems quickly and easily. They make fewer mistakes and take lesser time in forming different concepts. They have positive and significant correlation with different components of verbal and figural creativity this states that bilinguals have more number of ideas to work with words, they have ability to play with words, they have well versed vocabulary and produce novel and unusual responses with detailed information, they are witty thinkers, have higher creative strength and embroider or design the response with keen details, but intelligence show no relation with verbal flexibility as compared to figural creativity. The similar findings were reported about positive relationship between bilingualism and intelligence. It was pointed out that the more diversified socio-linguistic background of bilinguals favours the development of a more complex structure of mental abilities for them than for monolinguals. Bilinguals were additionally found superior on both verbal and nonverbal tests of intelligence [11].

Gueye focused on the relationship between bilingualism, intelligent quotient and errors made by learners in their attempt to master the rules of the target languages and showed that the relation between intelligent quotient and linguistic performance is rather correlational and not causal. The mistakes which occur at phonological, syntactic, semantic and stylistic levels in a written discourse of foreign language learning by the student are part and parcel of the learning process and may not be considered as the sign of lack of intelligence on the part of the learner. Thus, the author concluded that there is a correlation between intelligent quotient and bilingualism and errors or mistakes committed have to be tactfully handled by the teachers by giving a positive feedback to the students and making them more apt in learning a foreign language [14]. Researchers also support for the positive relationship between bilingualism and mathematics [15], [16], [17].

However, the literature on bilingualism included few studies examining the effect of degree of bilingualism in mathematical word problem solving and the ways in which balanced bilinguals demonstrate their mental flexibilities when faced with challenging mathematical word problems expressed in two languages of testing. When four and five year old bilingual children were examined and relationship between object-naming ability and bilingualism was studied by applying Vygotsky's approach it was found that Fifty-Four percent of these children consistently chose to interpret words in semantic dimensions. A higher percentage of the bilinguals perceived a relationship between words in their symbolic meaning rather than their sounds. The conclusions of these findings suggested that bilinguals reached a stage in semantic development two to three years earlier than monolinguals [27], [53]. Many studies have established the relationship between bilingualism and creativity [54], [55], [56], [57], [58], [30], [31], [59], [60], [61], [62], [63], [64]. The majority of these investigators have reported that bilingual people have higher performance on creativity measure when compared to monolingual people, suggesting a positive relationship between bilingualism and creativity. However, it is important to note that significant differences were not obtained on all the measures of creativity (i.e. verbal and figural fluency, flexibility, originality, and elaboration). Similar relationship between bilingualism and creativity of Nigerian and Welsh children was investigated and it was seen that bilingual children scored significantly higher on verbal creativity tests than their monolingual counterparts. However, no significant differences were found between the groups with respect to figural creativity [30]. Researchers examined a similar relationship among different degrees of bilingualism and creativity (adaptive creative style, innovative creative style, creative strengths). A total of 116 Korean American boys (49) and girls (65) with mean age of 11.8 and 11.3 respectively participated in the study. The Word Association Test and the Subjective Self Rating were used to determine the degree of bilingualism, and the Torrance Test of Creative Thinking-Figural test was used to measure creative potential. The results indicated that the degree of bilingualism was positively associated with creativity, and more specifically, with the adaptive creative style and creative strengths [35]. Studying the relationship between language learning strategies and EFL learners' creativity indicated that there is significant relationship between EFL learners total use of language learning strategies and their creative abilities [36].

\subsection{MONOLINGUAL (BOYS AND GIRLS)}

DOI: 10.9790/0837-2204025363

www.iosrjournals.org

$60 \mid$ Page 
From the results of correlational matrix of monolingual boys and girls we found that monolinguals posses fewer abilities than bilinguals to solve problems due to their linguistic repertoire, as exposure to only one language hinders their mental abilities. Intelligence is positively related to all the components of verbal and figural creativity except figural originality, which shows that monolinguals also possess the ability to produce numerous ideas, give responses which are unique, unexpected and unusual; they add pertinent details to the usual responses but cannot produce original ideas regarding the pictorial responses. Bound studied the relationship between linguistic background and nonverbal intelligence and found that bilingual group was superior on a test of nonverbal intelligence than monolingual group; however no difference was obtained between the groups with respect to English vocabulary level [65]. Researchers noted that monolingual third, fourth and fifth grade students in Singapore were more fluent than their bilingual peers. With respect to figural flexibility, the results were same as for figural fluency, except in the fourth grade when bilingual students performed better than monolingual students in the creativity tests. No significant differences between the groups were found regarding originality. Bilingual children outperformed monolingual children only in the figural elaboration measure [58]. A study conducted to compare the performance of Russian-English bilingual and English monolingual college students on the verbal and non verbal indicators of the abbreviated Torrance test for adults confirmed that the monolingual group obtained significantly higher scores compared with the bilingual group in verbal indicators of richness and colorfulness of imagery and future orientation. On the other side, bilingual group scored significantly higher than monolingual counterparts on the non verbal indicators of richness and colorfulness of imagery and resistance of premature closure [34].

\section{CONCLUSION}

After specifying the results and discussing them we conclude that both bilinguals and monolinguals show high and positive correlation between intelligence and the measures of creativity (i.e. Fluency, Flexibility, Originality and Elaboration) except verbal flexibility in case of bilinguals and figural originality in terms of monolinguals. Whereby bilinguals show a positive relation between intelligence and problem solving abilities monolinguals do not. Both the linguistic group show the similar relation between intelligence and conceptual development. The overall analysis indicates that bilingualism affects various cognitive abilities differently. The results also demonstrated that relationship between bilingualism and intelligence in particular is high and positive, therefore when the differences between bilinguals and monolinguals is assessed, they are always in favour of bilinguals.

\section{REFERENCES}

[1] B.L. Whorf, Language, thought and reality: Selected writings of Benjamin Lee Whorf: John B. Carroll (Ed) (Cambridge: MIT Press, 1956).

[2] E. Sapir, Culture, language and society: Selected essays. D.G. Mandelbaum (Ed.). Berkley (CA: University of California Press, 1956).

[3] R. Rotry, The linguistic turn( Chicago: UPC, 1992).

[4] L. S. Vygotsky, Mind in society: The development of higher psychological processes (Cambridge, Mass: Harvard University Press, 1978).

[5] J. Piaget, Piaget's theory, in P.H.Mussen (Ed.), Carmichael's manual of child psychology 3 (New York: Wiley, 1985)1,703-732.

[6] D. Crystal, The Cambridge encyclopedia of language (Cambridge: Cambridge University Press, 1987).

[7] J.C. Richards, R. Schmidt, Longman dictionary of language teaching and applied linguistics 3(Harlow, Essex: Longman, 2002).

[8] G. Valdez, R. A. Figueora, Bilingual and testing: A special case of bias (Norwood, NJ: Ablex Publishing Group ,1994).

[9] C. Baker, Foundations of bilingual education and bilingualism 1(Clevedon, UK: Multilingual Matters, 1993).

[10] E. Peal, W.E. Lambert, The relation of bilingualism to intelligence, Psychological Monographs: General and Applied, 76(546), 1962, 1-23.

[11] W.E. Lambert, E. Anisfeld, A note on the relationship of bilingualism and intelligence, Canadian Journal of Behavioral Sciences, 1, 1969, 123-128.

[12] N. Mazoochi, M. Saeidi, A comparative study on bilingual and monolingual Iranian EFL learners linguistic intelligence across genders, Journal of Life, 10(6), 2013, 321-334

[13] A. Fayyazi, R. Sahragard, B. Roshan, B. Zandi, Bilingual and monolingual differences on self-estimates of multiple intelligences regarding gender: A study of high school students in Iran, International Journal of Language Learning and Applied Linguistic World (IJLLALW), 4(4),2013, 513-533.

[14] M. Gueye, Some reflections on the relationship between bilingualism, Intelligent Quotient (IQ) and error making in teaching of English as a foreign language in Mali, Journal of Language Teaching and Research, 6(1), 2015, 85-90. http://dx.doi.org/10.17507/jtr.0601.10. 
[15] N. G. Hernandez, Diagnosing and remediating bilingual students in arithmetic, Focus in Learning Problems in Mathematics, 5, 1983, 15-22.

[16] S.M. Tuck, An investigation of the effectiveness of the Newman Language of mathematics kit, Major Project for the Masters of Education Studies in Mathematics, Monash University, 1983.

[17] P.C. Clarkson, P. Galbraith, Bilingualism and mathematics learning: Another perspective, Journal for Research in Mathematics Education, 23, 1992, 34-44.

[18] P.C. Clarkson, Language and mathematics: A comparison of bilingual and monolingual students of mathematics, Educational Studies in Mathematics, 23, 1992, 417-429.

[19] W. Kintsch, J.G. Greeno, Understanding and solving word arithmetic problems, Psychological Review, 92, 1985, 109-129.

[20] T.P. Carpenter, J. M. Moser, H. Bebout, Representation of addition and subtraction word problems, Journal for Research in Mathematics Education, 19, 1988, 345-357.

[21] E. Bialystok, Cognitive complexity and attentional control in the bilingual mind, Child Development, 70, 1999,636-644.

[22] E. Bialystok, F.I.M. Craik, R. Klein, M. Viswanathan, Bilingualism, aging and cognitive control: Evidence from the Simon task, Psychology and Aging, 19, 2004, 290-303.

[23] M. Obzori, A Comparative study of language learning strategies used by monolingual and bilingual EFL learners, Original Research Paper, 6, 2011, 41-53.

[24] F. Lauchlan, M. Parisi,R. Fadda, Bilingualism in Sardinia and Scotland: Exploring the cognitive benefits of speaking a 'minority' language, International Journal of Bilingualism, 17(1), 2012, 43-56.

[25] C. Feldman, M. Shen, Some language-related cognitive advantages of bilingual five-year-olds, Journal of Genetic Psychology, 118, 1971, 235-244.

[26] W.W. Liedtke, L.D. Nelson, Concept formation and bilingualism, Alberta Journal of Educational Research, 14, 1968, 225-232.

[27] A.D. Ianco-worral, Bilingualism and cognitive development, Child Development, 43, 1972 1390-1400.

[28] E. Bialystok, F.I.M. Craik, A.C. Ruocco, Dual-modality monitoring in a classification task: The effect of bilingualism and aging, The Quarterly Journal of Experimental Psychology, 59, 2006, 1968-1983.

[29] E. Bialystok, Effect of bilingualism and computer video game experience on the Simon task, Canadian Journal of Experimental Psychology, 60(1), 2006, 68-79.

[30] N. Okoh, Bilingualism and divergent thinking among Nigerian and Welsh school children, The Journal of Social Psychology, 110, 1980, 163-170.

[31] R. R. Wang, The relation between bilingualism and creative thinking [CD-ROM] (Abstracts from: Silver Platter File: Dissertation Abstracts Item: AAG8226795, 1982)

[32] A.V. Kharkhurin, The effect of linguistic proficiency, age of second language acquisition, and length of exposure to a new cultural environment on bilingual divergent thinking, Bilingualism: Language and Cognition, 11(2), 2008, 225-243.

[33] A.V. Kharkhurin, The role of bilingualism in creative performance on divergent thinking and invented alien creatures tests, Journal of Creative Behavior, 43(1), 2009, 59-71.

[34] A.V. Kharkhurin, Bilingual verbal and nonverbal creative behaviour, International Journal of Bilingualism, 14(2), 2010, 211-226.

[35] [35] H.E. Lee, K.H. Kim, Relationship between bilingualism and adaptive creative style, innovative creative style, and creative strengths among Korean American students, Creativity Research journal. 22(4), 2010, 402407.

[36] M. Nosratinia, Z. Mojri, E. Sarabchian, Creativity and language learning strategies: Towards a more successful language learning, International Journal of Scientific \& Engineering Research, 5(2), 2014, 1156-1170.

[37] M. Leikin, E. Tovli, S. Malykh, Bilingualism and creative abilities in early childhood, English Linguistic Research, 3(2), 2014, 54-63. doi:10.5430/elr.v3n2p54.

[38] S. Sehic, College - level second language courses and creative thinking skills : An ex post facto study, Doctoral dissertation,. Retrieved from http:// search. Proquest. Com/docview/1821932457, 2016.

[39] M. Leikin, The effect of bilingualism on creativity: Developmental and educational perspectives, International journal of bilingualism. 17(4), 2012, 431- 477.

[40] A.V. Kharkhurin, On the possible relationship between bilingualism, biculturalism and creativity: A cognitive perspective. A Dissertation Submitted to the Graduate Faculty in Psychology in Partial Fulfilment of the requirements for the degree of Doctoral of Philosophy, the City University of New York, 2005.

[41] J.C. Raven, Standard Progressive Matrices (H.K. Lewis \& Co. 1td, London. University Press Cambridge, 1984).

[42] L.N. Dubey, Manual for Problem Solving Ability Test (National Psychological Corporation, Agra, India, 2011). 
[43] E. Hoffman, J. Kansanian, Concept Formation Test performance type (National Psychological Corporation, Agra, India, 2005).

[44] E.P. Torrance, The manifesto: A guide to developing a creative career (West Westport, CT: Ablex, 2002).

[45] E.P. Torrance, The Torrance Tests of Creative Thinking. Norms-Technical Manual Research Edition-Verbal Tests, Forms A and B-Figural Tests, Forms A and B (Princeton, NJ: Personnel Press, 966).

[46] E. P. Torrance, (1974), The Torrance Tests of Creative Thinking. Norms-Technical Manual Research EditionVerbal Tests, Forms A and B- Figural Tests, Forms A and B (Princeton, NJ: Personnel Press, 1974).

[47] E.P. Torrance, O.E. Ball, The Torrance tests of creative thinking streamlined (revised) manual, Figural forms A and B (Bensenville, IL: Scholastic Testing Service, Inc, 1984).

[48] E.P. Torrance (1990). The Torrance tests of creative thinking. Norms - technical manual figural (streamlined) forms A \& B (Bensenville, IL: Scholastic Testing Service, Inc, 1990).

[49] E.P. Torrance, The Torrance tests of creative thinking. Norms - technical manual figural (streamlined) forms A \& B (Bensenville, IL: Scholastic Testing Service, Inc, 1998).

[50] E.P. Torrance, The manifesto: A guide to developing a creative career (West Westport, CT: Ablex, 2002).

[51] J.P. Guilford, Personality (New York: McGraw-Hill, 1959).

[52] J.P. Guilford, Fundamental statistics in psychology and education 5(McGraw-Hill, Kogakusha LTD, 1978).

[53] L.S. Vygotsky, Thought and language (Cambridge, Mass: MIT Press, 1962).

[54] J.F. Jacobs, M. L. Pierce, Bilingualism and creativity. Elementary English, 43,1966, 499-503.

[55] R.G Landry, Bilingualism and Creative abilities, Unpublished manuscript, North Dakota State University Fargo, Eric Document Reproduction Service No. ED 039 602, 1968.

[56] C. Jansen, A study of bilingualism and creativity. Paper presented at the convention of the American personnel and guidance association, Las Vegas, NV, ERIC Document Reproduction Service No. ED 034269, 1969.

[57] D.C. Carringer, Creative thinking abilities of Mexican youth, Journal of Cross-cultural Psychology,5, 1974, 492504.

[58] E.P. Torrance, J.J. Wu, J. C. Gowan, N. Alliotti, Creativity functioning of monolingual and bilingual children in Singapore, Journal of Educational Psychology, 61, 1970, 72

[59] C. Kessler, M. E. Quinn, Language minority children's linguistic and cognitive creativity, Journal of Multilingual and Multicultural Development, 8, 1987, 173-186.

[60] L.H. Corbett, Effect of bilingualism on humor and creativity [CD-ROM], Abstract from:Silver Platter File, Dissertation Abstracts Item, AAC9117270, 1990.

[61] M.F. Martorell, Language Proficiency and Locus- of -Control among Hispanic Bilingual Gifted Children [CDROM], Abstract From Silver Platter File, Dissertation Abstracts Item: AAC9136330, 1991.

[62] L.A. Ricciardelli, Creativity and bilingualism, Journal of Creative behavior, 26(4),1992, 242-254.

[63] S. Stone, Divergent thinking: Nontraditional or creative talents of monolingual, bilingual, and special education students in an elementary school [CD-ROM], Abstracts from: Silver Platter File, Dissertation Abstracts Item: AA (923880), 1992.

[64] K. Konaka, The relationship between degree of bilingualism and gender to divergent thinking ability among native Japanese-speaking children in the New York area [CD-ROM], Abstract from: Silver Platter File, Dissertation Abstracts Item: AAG9718715, 1997.

[65] A.D. Bound, Linguistic background and nonverbal intelligence: A cross-cultural comparison, The Journal of Educational Research. 68(1), 1974, 26-27. 